\title{
SISTEM INFORMASI GEOGRAFIS PEMETAAN SEKOLAH TINGKAT PENDIDIKAN DASAR DAN MENENGAH DI KOTA SERANG
}

\author{
Siti Suryani, Priyo Sidik Sasongko, dan Edy Suharto
}

\author{
Program Studi Teknik Informatika, Fakultas MIPA, Universitas Diponegoro \\ nie.majesty@gmail.com
}

\begin{abstract}
The Spatial-based information system is one of the systems that is needed nowadays, because it serves as a foundation in supporting variety of applications in various sectors, one of which is education. Serang as the capital of Banten province indubitably becomes a model reference for other districts and cities in the development of education. Providing information regarding education, especially schools, to the people is of major importance to enhance Serang education office activity in providing service. There has not been any spatial-based information about schools in the city of Serang yet, so it is necessary to have a geographic information system of school mapping. Geographic information system of school mapping in Serang was developed using the waterfall model and built using MapServer, PHP programming language, and MySQL database management system. The system provides information on the distribution of both public and private primary education (SD/MI), secondary education (SMP/MTs), and upper secondary and vocational education (SMA/MA/SMK) in the city in the form of digital maps, containing spatial data and attribute data, and also generates information about indicators of equality on learning opportunity and gross participation rate (APK) in the city of Serang.
\end{abstract}

Keywords: geographic information system, school mapping, waterfall model

\section{Pendahuluan}

Perkembangan pemanfaatan data spasial dalam dekade belakangan ini meningkat dengan sangat drastis. Hal ini berkaitan dengan meluasnya pemanfaatan Sistem Informasi Geografis (SIG) dan perkembangan teknologi dalam memperoleh, merekam, dan mengumpulkan data yang bersifat keruangan (spasial). Sistem informasi atau data yang berbasiskan keruangan pada saat ini merupakan salah satu elemen yang sangat penting, karena berfungsi sebagai pondasi dalam melaksanakan dan mendukung berbagai macam aplikasi. Sebagai contoh aplikasi yang dapat dibuat dengan dasar SIG adalah pemetaan sekolah.

Kota Serang sebagai ibukota dari provinsi Banten menjadi acuan bagi kabupaten/kota lain dalam perkembangan di berbagai sektor, salah satunya pendidikan. Dinas Pendidikan Kota Serang mempunyai tugas melaksanakan pelayanan bidang pendidikan di wilayah Kota Serang. Penyediaan informasi kepada masyarakat mengenai pendidikan, khususnya sekolah, menjadi hal yang sangat penting guna mendukung kegiatan pelayanan Dinas Pendidikan Kota Serang.

Salah satu media penyampaian informasi yang lengkap dan dapat diakses dengan cepat di mana saja adalah dengan menggunakan website. Kajian geografi juga menjadi hal yang cukup penting dalam penyampaian informasi sekolah.

Berdasarkan pertimbangan tersebut maka dibutuhkan suatu sistem informasi yang mampu membantu dinas pendidikan terkait dalam menyediakan sarana informasi geografis pemetaan sekolah bagi masyarakat Kota Serang.

Tujuan dari penelitian ini adalah untuk merancang dan membangun sebuah sistem informasi geografis pemetaan sekolah di wilayah Kota Serang yang berbasis web.

\section{Tinjauan Pustaka}

Menurut data dari Badan Perencanaan Pembangunan Daerah (Bappeda) Kota Serang, Kota Serang merupakan ibukota Provinsi Banten yang memiliki total luas wilayah sebesar 266,74 $\mathrm{km} 2$. Luas wilayah tersebut terbagi atas 66 desa/kelurahan, yang termasuk dalam 6 
kecamatan, yaitu Kecamatan Serang, Kecamatan Cipocok Jaya, Kecamatan Curug, Kecamatan Walantaka, Kecamatan Taktakan, dan Kecamatan Kasemen [3].

Menurut Peraturan Daerah Kota Serang Nomor 9 Tahun 2008 tentang Pembentukan dan Susunan Organisasi Dinas Daerah Kota Serang, dinas pendidikan adalah unsur pelaksana otonomi daerah yang menyelenggarakan pelayanan bidang pendidikan. Dinas pendidikan dipimpin oleh Kepala Dinas yang berkedudukan di bawah Walikota dan bertanggungjawab kepada Walikota melalui Sekretaris Daerah [8].

Sistem informasi merupakan suatu sistem yang tujuannya menghasilkan informasi [6]. Sistem Informasi Geografis atau SIG merupakan sejenis perangkat lunak yang dapat digunakan untuk memasukkan, menyimpan, memanipulasi, dan menampilkan informasi geografis berikut atribut-atributnya [9].

Komponen SIG adalah sistem komputer, data geospasial, dan pengguna [11].. SIG mengolah 2 macam data yaitu data geospasial atau yang biasanya disebut data spasial dan data nonspasial (atribut). Jika pada Gambar 2.1 data atribut tidak digambarkan karena memang dalam SIG yang dipentingkan adalah tampilan data secara spasial, walaupun sebenarnya pada SIG kadang-kadang juga melibatkan data atribut, baik secara langsung maupun tidak langsung.

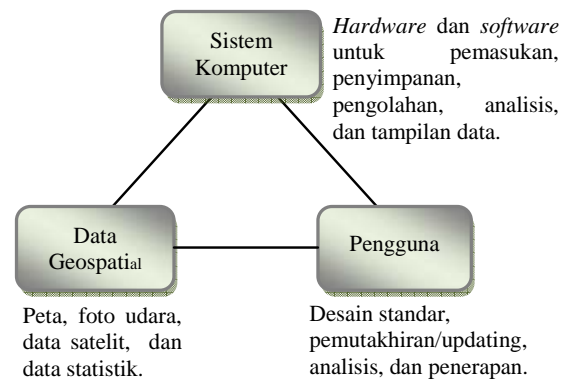

Gambar 1. Komponen Kunci SIG (Qolis, 2010)

Web-GIS atau Web-Geographic Information System adalah aplikasi GIS atau pemetaan digital yang memanfaatkan jaringan Internet sebagai media komunikasi yang berfungsi mendistribusikan, mempublikasikan, mengintegrasikan, mengkomunikasikan, dan menyediakan informasi dalam bentuk teks dan peta digital, serta menjalankan fungsi-fungsi analisis dan query yang terkait dengan GIS melalui jaringan Internet [10].

Secara umum sistem informasi geografis dikembangkan berdasarkan pada prinsip masukan data, manajemen, analisis, dan representasi data [4]. Di lingkungan web prinsipprinsip tersebut digambarkan dan diimplementasikan seperti pada Tabel 1 .

Tabel 1. Prinsip SIG dalam Lingkungan web

\begin{tabular}{|l|l|}
\hline \multicolumn{1}{|c|}{ Prinsip SIG } & \multicolumn{1}{|c|}{ Pengembangan Web } \\
\hline Masukan data & Client \\
\hline Manajemen data & $\begin{array}{l}\text { DBMS dengan komponen } \\
\text { spasial }\end{array}$ \\
\hline Analisis data & GIS Library di server \\
\hline $\begin{array}{l}\text { Representasi } \\
\text { data }\end{array}$ & Client/server \\
\hline
\end{tabular}

MapServer merupakan aplikasi freeware dan open source yang dapat menampilkan data spasial (peta) di web [7]. Selain dapat mengakses MapServer sebagai program CGI, pengembang juga dapat mengakses MapServer sebagai modul MapScript, melalui berbagai bahasa skrip : PHP, Python, atau Java. Akses fungsi-fungsi MapServer melalui skrip lebih memudahkan pengembangan aplikasi. Pengembang dapat memilih bahasa pemrograman yang paling familiar.

Pada pembangunan sistem ini model proses perangkat lunak yang digunakan adalah waterfall model. Waterfall model merupakan pendekatan secara sistematik dan sekuensial untuk pengembangan perangkat lunak yang berjalan melalui tahapan demi tahapan [13].

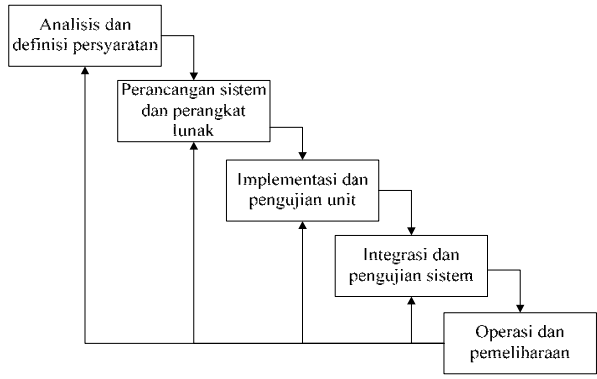

Gambar 2. Waterfall Model (Sommerville, 2003) 
Tahap-tahap utama dari waterfall model ini memetakan kegiatan-kegiatan pengembangan dasar yaitu :

a. Analisis dan Definisi Persyaratan Informasi yang dapat digunakan untuk mendukung pengembangan perangkat lunak diperoleh melalui konsultasi dengan pengguna sistem. Pada tahapan ini diperoleh SRS (Software Requirements Specification) yang kemudian menjadi fungsionalitas dari perangkat lunak yang dibangun. SRS adalah dokumen yang berisi deskripsi lengkap mengenai apa kemampuan perangkat lunak (what) tanpa menjelaskan bagaimana (how) perangkat lunak melaksanakan kemampuan tersebut.

\section{- Pemodelan Data}

Pemodelan data berfungsi untuk mendeskripsikan objek data utama yang diproses oleh sistem, komposisi dari masing-masing objek data, dan atribut apa yang menggambarkan objek tersebut, serta hubungan antara objek data tersebut. Metode pemodelan data menggunakan Entity Relationship Diagram (ERD) mendeskripsikan berbagai hal tersebut.

Entity Relationship Diagram (ERD) terdiri atas sekumpulan objek yang disebut dengan himpunan entitas dan hubungan yang terjadi pada objek-objek tersebut [14].

\section{- Pemodelan Fungsional}

Pemodelan fungsional menggambarkan keseluruhan fungsi dari suatu sistem sebagai sebuah transformasi dari input yang diberikan user menjadi output yang dihasilkan oleh sistem. Alat bantu yang digunakan dalam melakukan pemodelan fungsional ini adalah DFD (Data Flow Diagram). DFD merupakan model dari sistem untuk menggambarkan pembagian sistem ke modul yang lebih kecil [1].

b. Perancangan Sistem dan Perangkat Lunak Proses perancangan sistem membagi persyaratan dalam sistem perangkat keras atau perangkat lunak. Kegiatan ini menentukan arsitektur sistem secara keseluruhan. Perancangan perangkat lunak melibatkan identifikasi dan deskripsi abstrak sistem perangkat lunak yang mendasar dan hubungan-hubungannya.

c. Implementasi dan Pengujian Unit

Pada tahap ini perancangan perangkat lunak direalisasikan sebagai serangkaian program atau unit program. Pengujian unit melibatkan verifikasi bahwa setiap unit telah memenuhi spesifikasinya.

d. Integrasi dan Pengujian Sistem

Unit program atau program individual diintegrasikan dan diuji sebagai sistem yang lengkap untuk menjamin bahwa persyaratan sistem telah dipenuhi. Pengujian sistem menggunakan metode black box yaitu pengujian yang difokuskan pada fungsionalitas perangkat lunak tanpa pengetahuan struktur internal program (source code). Setelah pengujian sistem selesai, perangkat lunak dikirim kepada pengguna sistem.

e. Operasi dan Pemeliharaan

Tahap ini merupakan tahap siklus hidup yang paling lama. Pada tahap ini dilakukan instalasi dan penggunaan sistem. Pemeliharaan mencakup koreksi dari berbagai bug yang tidak ditemukan pada tahap-tahap terdahulu, perbaikan atas implementasi unit sistem, dan pengembangan pelayanan sistem.

Indikator merupakan suatu konsep dan sekaligus ukuran. Sebagai suatu konsep, indikator pendidikan merupakan besaran kuantitatif mengenai suatu konsep tertentu yang dapat digunakan untuk mengukur proses dan hasil pendidikan atau dampak dari suatu instrumen kebijakan pendidikan. Indikator juga didefinisikan sebagai perbandingan antara dua atau lebih variabel sehingga dapat diinterpretasikan [2].

Data Statistik Indonesia (http://www.datastatistik-indonesia.com) mendefinisikan Angka Partisipasi Kasar (APK) sebagai rasio jumlah siswa, berapapun usianya, yang sedang sekolah di jenjang pendidikan tertentu terhadap jumlah penduduk kelompok usia yang berkaitan dengan jenjang pendidikan tertentu [5].

APK berguna untuk mengetahui banyaknya anak usia sekolah yang bersekolah di suatu 
jenjang pendidikan.tertentu dan untuk menunjukkan tingkat partisipasi penduduk secara umum di suatu jenjang pendidikan tertentu. APK merupakan indikator yang paling sederhana untuk mengukur daya serap penduduk usia sekolah di masing-masing jenjang pendidikan [2].

$\mathrm{APK}=\frac{\text { Jumlah siswa pada jenjang pendidikan tertentu }}{\text { Jumlah penduduk kelompok usia tertentu*) }} \times 100 \%$

*) Tingkat SD/MI : kelompok usia 7 - 12 tahun Tingkat SMP/MTs: kelompok usia $13-15$ tahun

Tingkat SMA/MA/SMK: kelompok usia 16 - 18 tahun.

Makin tinggi APK berarti makin banyak anak usia sekolah yang bersekolah di suatu daerah, atau makin banyak anak usia di luar kelompok usia sekolah tertentu yang bersekolah di jenjang pendidikan tertentu. Nilainya APK bisa lebih besar dari 100\% karena adanya siswa di luar usia sekolah, daerah kota, atau daerah perbatasan.

Indikator pemerataan kesempatan belajar adalah rasio daya tampung sekolah pada jenjang pendidikan tertentu terhadap jumlah penduduk kelompok usia yang berkaitan dengan jenjang pendidikan tertentu. Indikator ini berguna untuk menunjukkan tingkat pemerataan dalam memperoleh kesempatan pendidikan untuk masyarakat pada suatu wilayah tertentu.

Indikator pemerataan kesempatan belajar bernilai terpenuhi apabila jumlah daya tampung sekolah pada jenjang pendidikan tertentu lebih besar daripada jumlah penduduk kelompok usia pada jenjang pendidikan tersebut. Indikator pemerataan kesempatan belajar bernilai tidak terpenuhi apabila jumlah daya tampung sekolah pada jenjang pendidikan tertentu lebih kecil daripada jumlah penduduk kelompok usia pada jenjang pendidikan tersebut.

Melalui indikator angka partisipasi kasar dan indikator pemerataan kesempatan belajar, dapat disusun suatu perencanaan untuk mengatasi masalah pemerataan pada masing-masing jenjang pendidikan.

\section{Analisis dan Perancangan}

\subsection{Analisis}

Perspektif produk sistem dapat dilihat pada Gambar 3.

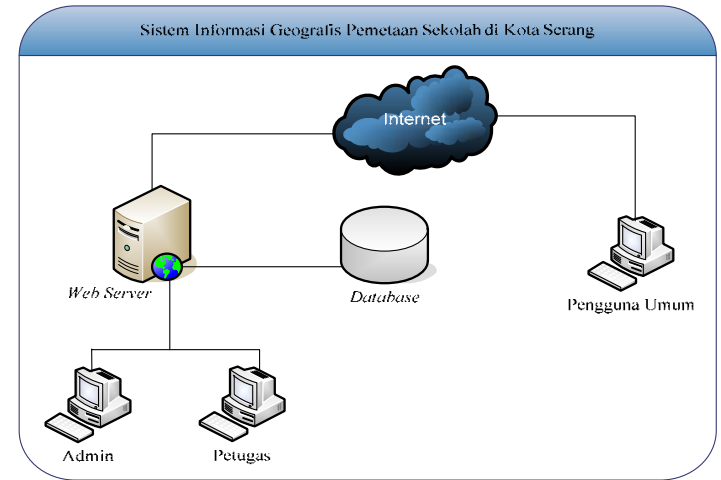

Gambar 3. Perspektif Produk SIG Pemetaan

Sekolah

Proses yang dapat dijelaskan pada arsitektur sistem tersebut adalah ketika sistem dijalankan, sistem membutuhkan data yang tersimpan dalam sebuah database. Database tersebut terkoneksi ke web server. Untuk mengelola data yang ada pada database, komputer admin dan petugas harus menggunakan web server terlebih dahulu untuk mendapatkan ijin akses. Admin bertanggung jawab secara teknis terhadap jalannya aplikasi. Petugas bertanggung jawab terhadap pengelolaan data sekolah. Sedangkan pengguna umum merupakan masyarakat yang dapat melihat informasi sekolah.

Dalam pengembangan sistem ini terdapat beberapa asumsi dan batasan yang digunakan, yaitu:

a. Sistem informasi geografis pemetaan sekolah di Kota Serang dibangun untuk diimplementasikan pada Dinas Pendidikan Kota Serang.

b. Data yang ada pada sistem ini merupakan data tahun 2010 berupa data wilayah.

c. Kota Serang dan data sekolah yang didapat dari Badan Perencanaan Pembangunan Daerah Kota Serang dan Dinas Pendidikan Kota Serang.

d. Sekolah yang dimaksud dalam sistem ini adalah sekolah tingkat dasar (Sekolah Dasar/Madrasah Ibtida'iyah), tingkat menengah pertama (Sekolah Menengah Pertama/Madrasah Tsanawiyah), dan tingkat menengah atas dan kejuruan (Sekolah Menengah Atas/Madrasah Aliyah/Sekolah Menengah Kejuruan), baik yang berstatus negeri maupun swasta. 
e. Data jumlah penduduk dalam sistem ini mengalami perubahan setiap periode tahunan.

f. Sistem ini tidak menangani masalah pertambahan atau pengurangan jumlah penduduk yang disebabkan kepindahan daerah.

g. Daya tampung sekolah adalah kapasitas sekolah dalam menampung jumlah peserta didik atau pelajar.

h. Rombongan belajar adalah kelompok peserta didik yang terdaftar pada satu satuan kelas.

i. Terdapat pembagian kelas pagi dan kelas sore apabila jumlah pelajar dalam suatu sekolah lebih besar dari daya tampung sekolah tersebut.

j. Pengguna sistem ini terdiri atas 3 golongan, yaitu admin, petugas, dan pengguna umum.

- Pegawai Dinas Pendidikan Kota Serang bertindak sebagai admin yang mengelola data sekolah, data desa, dan data user.

- Pegawai Dinas Pendidikan Kota Serang Bidang Pembinaan TK/SD, SMP/MTs, dan SMA/SMK bertindak sebagai user petugas yang mengelola data sekolah sesuai masing-masing bidang.

- Masyarakat yang mengakses sistem ini berperan sebagai pengguna umum yang hanya dapat melihat informasi sekolah.

k. Sistem ini menyajikan indikator pemerataan kesempatan belajar dan Angka Partisipasi Kasar (APK) yang berguna untuk mendukung analisis terhadap tingkat pemerataan kesempatan belajar dan tingkat partisipasi penduduk pada sektor pendidikan jenjang SD/MI, SMP/MTs, dan SMA/MA/SMK di wilayah Kota Serang, seperti yang telah dijelaskan pada subbab Tinjauan Pustaka.

Kemampuan fungsional sistem informasi geografis pemetaan sekolah di Kota Serang dijelaskan pada Tabel 2.

Tabel 2. Software Requirements Specification SIG Pemetaan Sekolah

\begin{tabular}{|c|c|l|}
\hline No. & Kode SRS & \multicolumn{1}{|c|}{ Keterangan } \\
\hline 1. & SRS-PS-F01 & Melakukan otentikasi \\
\hline 2. & SRS-PS-F02 & $\begin{array}{l}\text { Manajemen data } \\
\text { pengguna }\end{array}$ \\
\hline 3. & SRS-PS-F03 & Manajemen data sekolah \\
\hline 4. & SRS-PS-F04 & Manajemen data desa \\
\hline 5. & SRS-PS-F05 & $\begin{array}{l}\text { Menampilkan } \\
\text { kecamatan }\end{array}$ \\
\hline 6. & SRS-PS-F06 & $\begin{array}{l}\text { Menampilkan } \\
\text { persebaran sekolah }\end{array}$ \\
\hline 7. & SRS-PS-F07 & $\begin{array}{l}\text { Menampilkan informasi } \\
\text { sekolah }\end{array}$ \\
\hline 8. & SRS-PS-F08 & Pencarian sekolah \\
\hline 9. & SRS-PS-F09 & $\begin{array}{l}\text { Menampilkan informasi } \\
\text { indikator pemerataan } \\
\text { kesempatan belajar dan } \\
\text { angka partisipasi kasar }\end{array}$ \\
\hline
\end{tabular}

\subsubsection{Entity Relationship Diagram}

Gambar ERD sistem yang akan dibangun dapat dilihat pada Gambar 4. 


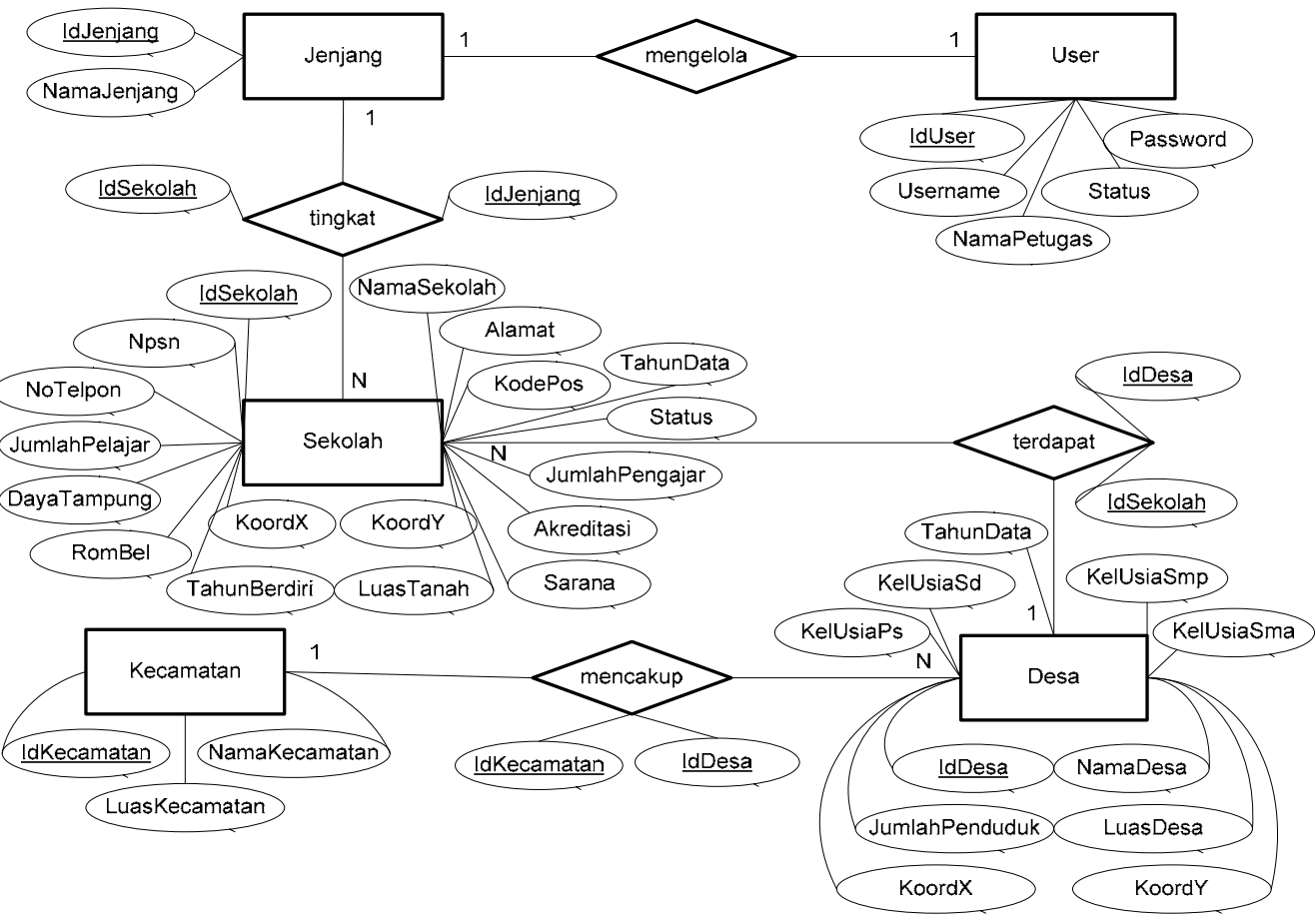

Gambar 4. ERD SIG Pemetaan Sekolah

\subsubsection{Data Context Diagram}

Data Context Diagram (DCD) atau Data Flow Diagram (DFD) level 0 dari sistem dapat dilihat pada Gambar 5.

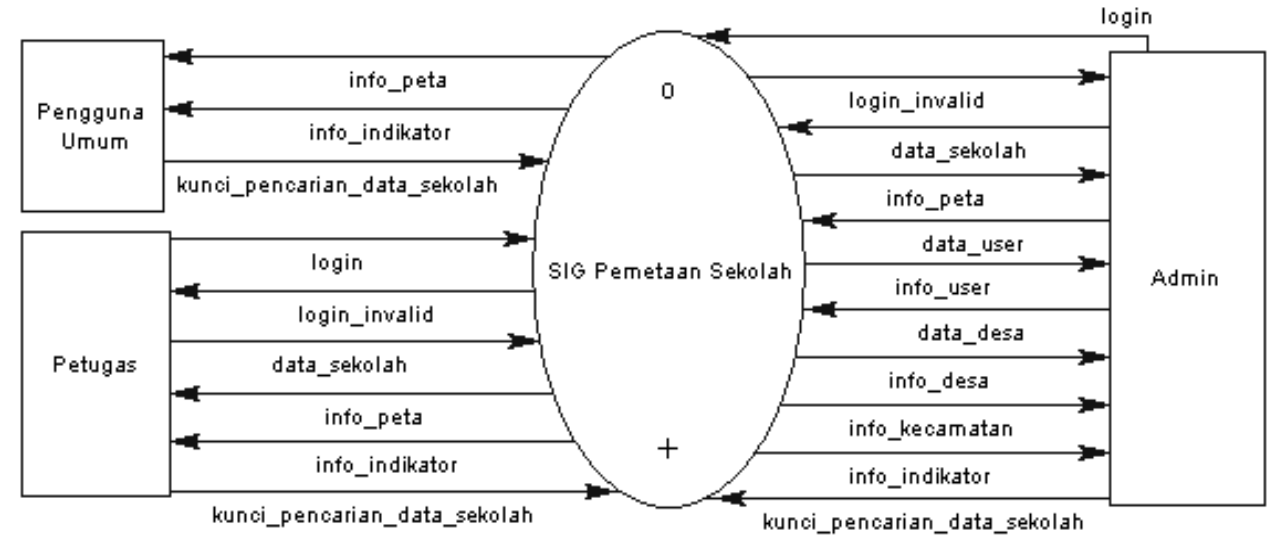

Gambar 5. DCD SIG Pemetaan Sekolah

\subsection{Perancangan}

\subsubsection{Perancangan Data}

Perancangan data merupakan transformasi model data yang dihasilkan dari ERD menjadi struktur data yang dibutuhkan pada saat implementasi.

Physical Data Model (PDM) merupakan model yang menggunakan sejumlah tabel untuk 
menggambarkan data serta hubungan antardata tersebut.

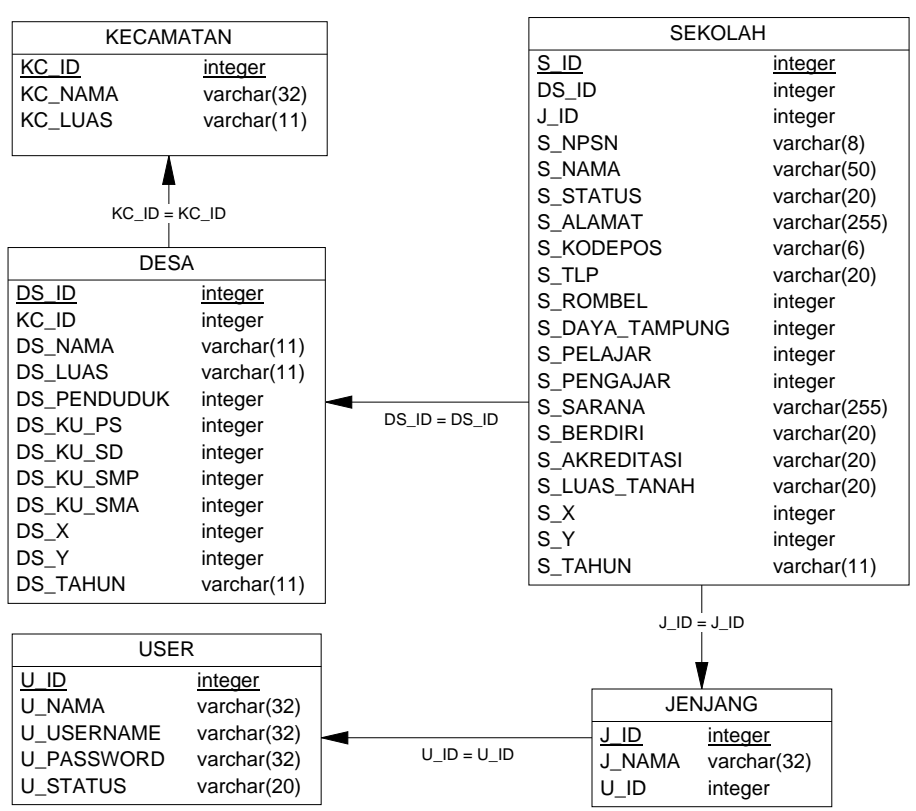

Gambar 6. PDM SIG Pemetaan Sekolah

\subsubsection{Perancangan Antarmuka}

Antarmuka menjembatani interaksi antara mesin dengan pengguna atau sistem dengan administrator. Perancangan antarmuka dapat menunjukkan bagaimana komunikasi antara pengguna sistem dengan komputer.
Struktur menu sistem informasi geografis pemetaan sekolah di Kota Serang dapat dilihat pada Gambar 7. Pengguna umum, petugas, dan admin dapat melihat menu profil kota, data sekolah, pemetaan sekolah, dan indikator analisis tanpa harus login terlebih dahulu. 


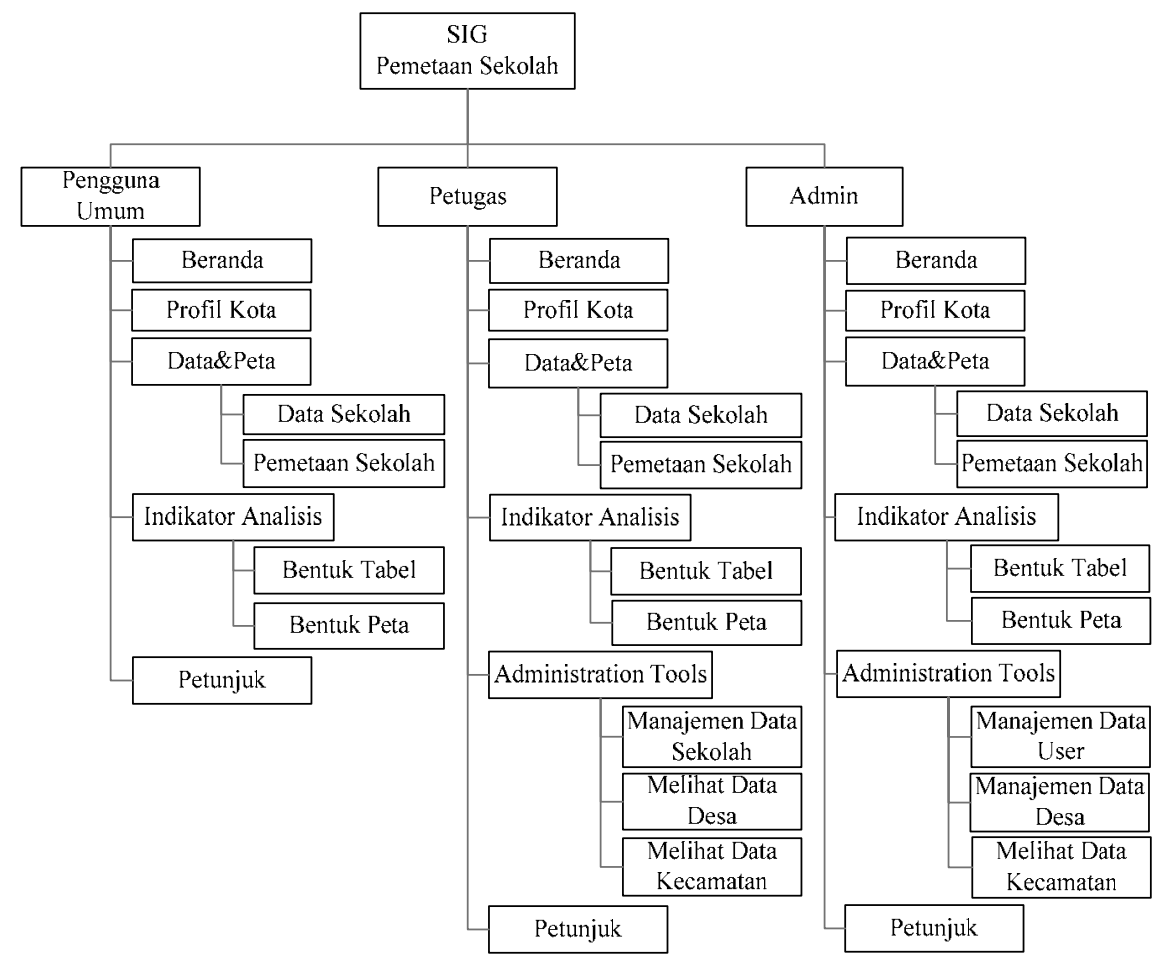

Gambar 7. Struktur Menu SIG Pemetaan Sekolah

Rancangan antarmuka SIG pemetaan sekolah ditunjukkan seperti Gambar 8, yang berisi tampilan peta sebaran sekolah di wilayah Kota

Serang beserta fungsi navigasi, pilihan aktifasi layer sekolah, legenda, hasil query informasi detail sekolah, dan pencarian lokasi sekolah.

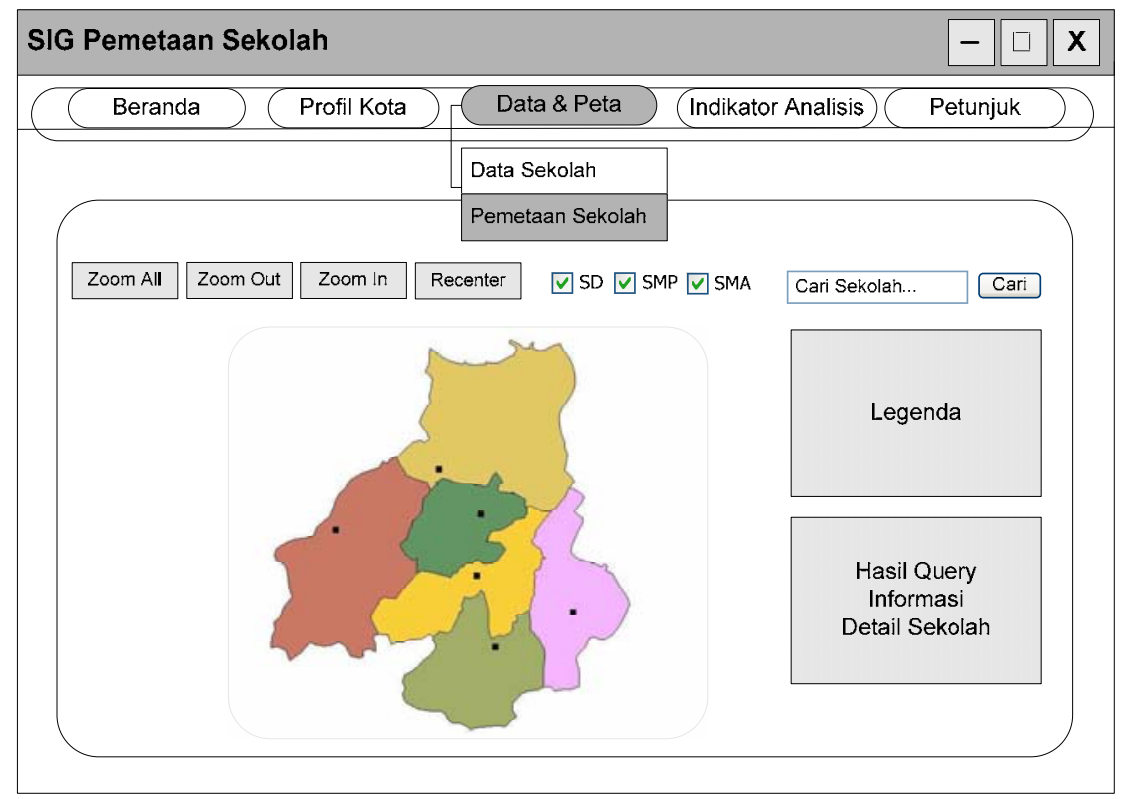

Gambar 8. Rancangan Antarmuka Menu Pemetaan Sekolah 


\section{Implementasi dan Pengujian}

4.1. Implementasi

Hasil implementasi ke dalam sistem informasi geografis, telah mampu memadukan keungguhan DBMS MySQL sebagai mesin database atribut dan MapServer sebagai mesin database spasial. Keduanya telah berhasil diimpelementasikan pada tampilan antarmuka sistem. Pengguna akan memperoleh kesatuan informasi secara spasial dan atribut.
Sistem informasi geografis ini dapat menampilkan peta interaktif persebaran sekolah beserta fungsi navigasi dan aktifasi layer, seperti yang dapat dilihat pada Gambar 9. Hasil query informasi detail sekolah muncul jika salah satu lokasi sekolah pada peta diklik. Lokasi sekolah yang diklik terlihat berkedip-kedip dan pada kotak sebelah kanan muncul informasi detail sekolah

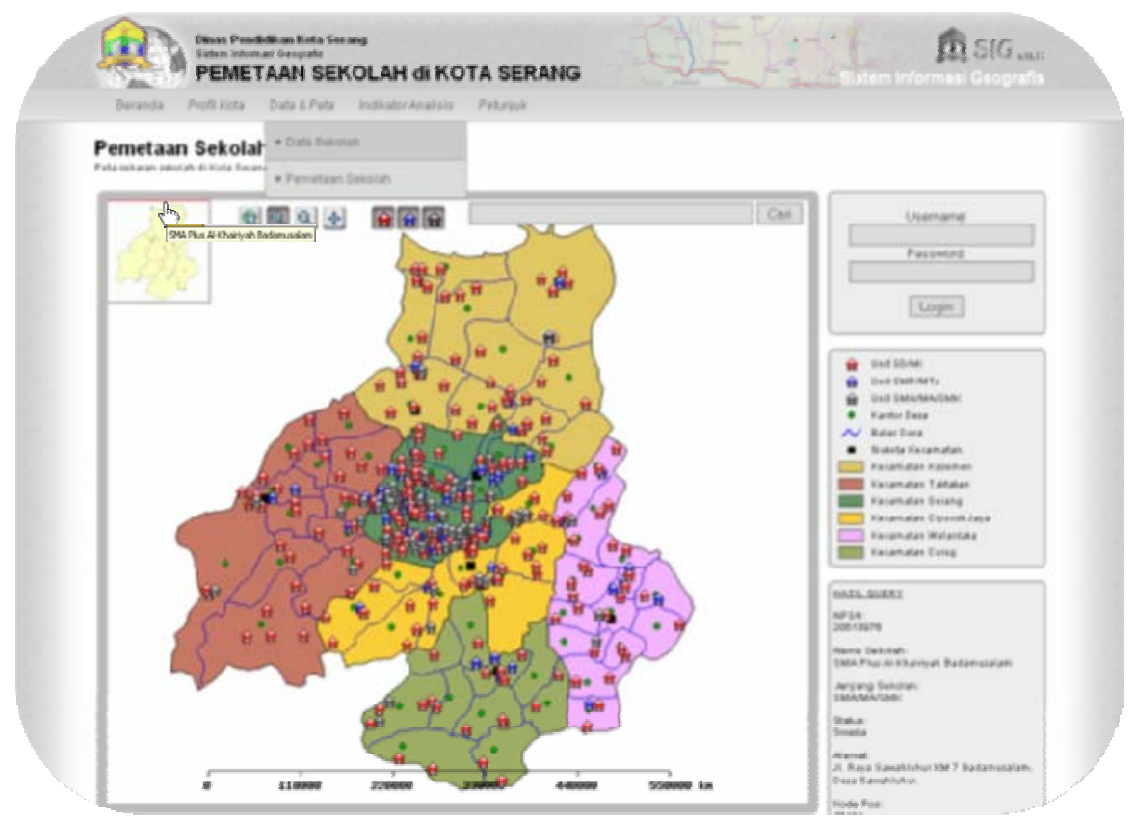

Gambar 9. Antarmuka Menu Pemetaan Sekolah

Sistem informasi geografis ini dapat SMA/MA/SMK. Pengelolaan data sekolah menangani pengelolaan data sekolah di Kota disajikan dalam bentuk tabel seperti pada Gambar Serang pada jenjang SD/MI, SMP/MTs, dan 10. 


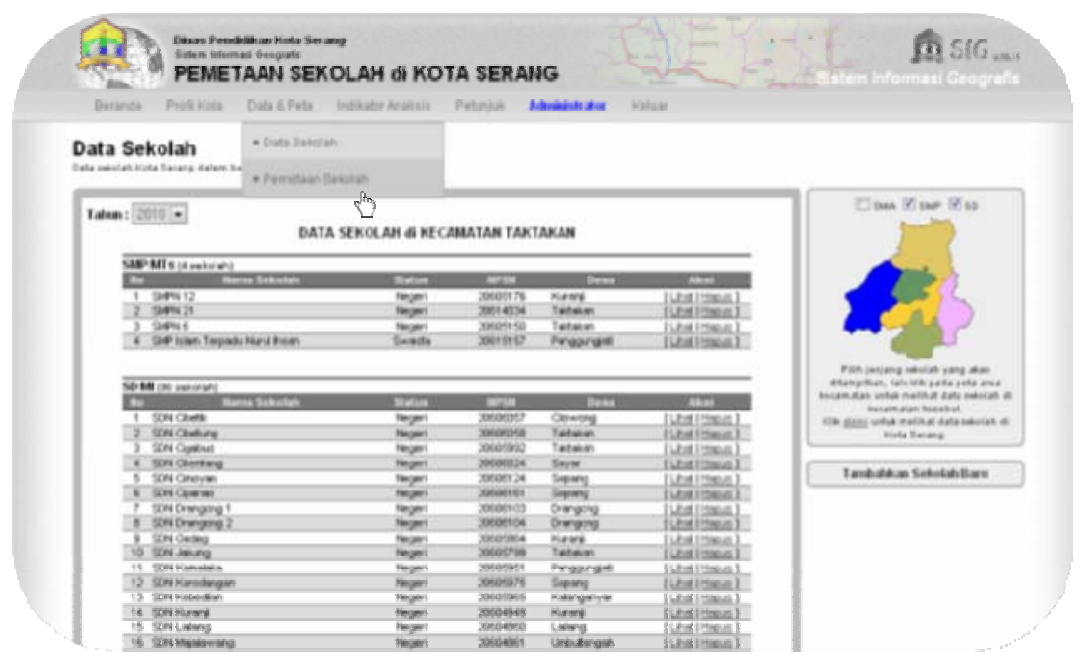

Gambar 10. Antarmuka Menu Data Sekolah

Selain pengelolaan data sekolah, sistem ini juga dapat menangani pengelolaan data desa, data kecamatan, dan data pengguna, yang seluruhnya menjadi hak otoritas admin.

Sistem informasi geografis ini juga dilengkapi kemampuan untuk menampilkan indikator analisis pemerataan kesempatan belajar dan angka partisipasi kasar yang dapat diakses pada menu indikator analisis.
Tampilan antarmuka menu indikator analisis dalam bentuk peta dapat dilihat pada Gambar 11 . Pemenuhan indikator pemerataan kesempatan belajar didapat dari ketentuan yang telah dijelaskan pada subbab Tinjauan Pustaka. Wilayah yang berwarna hijau merupakan wilayah yang memenuhi indikator pemerataan kesempatan belajar, yaitu wilayah yang memiliki daya tampung sekolah lebih besar dari jumlah penduduk kelompok usia jenjang pendidikan tertentu.

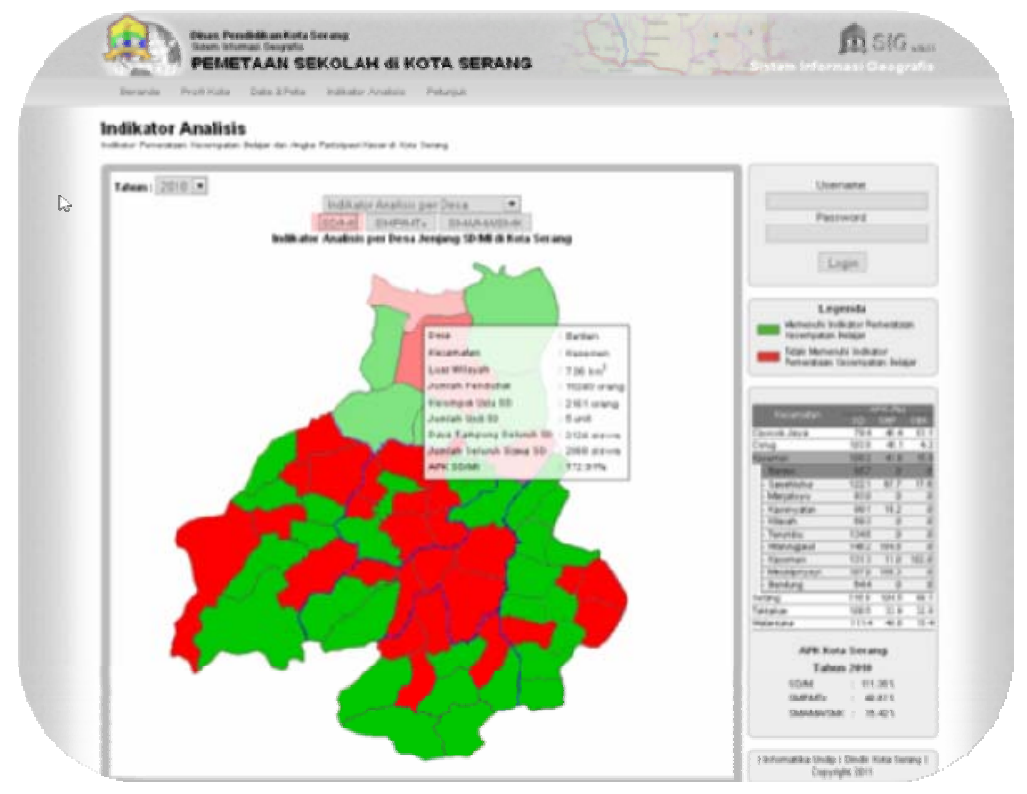

Gambar 11. Antarmuka Menu Indikator Analisis dalam Bentuk Peta 
Sedangkan wilayah yang berwarna merah merupakan wilayah yang tidak memenuhi indikator pemerataan kesempatan belajar, yaitu daya tampung sekolah lebih kecil dari jumlah penduduk kelompok usia jenjang pendidikan tertentu.

Nilai APK merupakan persentase dari rasio jumlah pelajar jenjang pendidikan tertentu dengan jumlah penduduk kelompok usia jenjang pendidikan tertentu.

\subsection{Pengujian}

Pengujian adalah proses mengeksekusi suatu program untuk menemukan kesalahan-kesalahan agar dapat diperbaiki sedini mungkin, sehingga dapat menjamin program tersebut memenuhi spesifikasi yang telah ditentukan dari awal pembuatan. Pengujian sistem informasi geografis pemetaan sekolah dilakukan pada persyaratan fungsional perangkat lunak (black box) dengan memasukkan serangkaian kondisi input yang sepenuhnya menggunakan persyaratan fungsional program dengan menggunakan koneksi localhost.

Dari hasil pengujian sistem informasi geografis pemetaan sekolah dapat diketahui bahwa sistem ini telah memenuhi untuk :

a. Melakukan otentikasi pengguna

b. Mencatat data sekolah, data desa, dan data user

c. Menampilkan peta persebaran sekolah dan informasi detail sekolah

d. Melakukan pencarian sekolah

e. Menampilkan indikator pemerataan kesempatan belajar dan Angka Partisipasi Kasar (APK) di Kota Serang.

\section{Kesimpulan}

Kesimpulan yang dapat diambil dalam pembangunan Sistem Informasi Geografis Pemetaan Sekolah Tingkat Pendidikan Dasar dan Menengah di Kota Serang ini adalah sebagai berikut :

a. Sistem ini dapat menampilkan informasi persebaran sekolah jenjang pendidikan dasar (SD/MI), pendidikan menengah pertama (SMP/MTs), dan pendidikan menengah atas dan menengah kejuruan (SMA/MA/SMK) yang berstatus negeri maupun swasta dalam bentuk peta interaktif, berupa data spasial dan data atribut.

b. Sistem ini dapat menghasilkan informasi indikator pemerataan kesempatan belajar untuk mendukung analisis tingkat pemerataan kesempatan memperoleh pendidikan di wilayah Kota Serang.

c. Sistem ini dapat menghasilkan indikator Angka Partisipasi Kasar (APK) untuk mendukung analisis tingkat partisipasi penduduk terhadap sektor pendidikan di wilayah Kota Serang.

\section{Daftar Pustaka}

[1] Al Bahra B., 2006, “Rekayasa Perangkat Lunak”, Graha Ilmu, Yogyakarta

[2] Anonim, 2011, "Data dan Indikator Pendidikan”, diakses dari http://pakguruonline.pendidikan.net/datordi k_1.html, pada tanggal 9 Februari 2011 pukul 11.44 WIB.

[3] Badan Perencanaan Pembangunan Daerah Kota Serang, 2009, “Kota Serang dalam Angka”, Bappeda, Serang.

[4] Charter D., 2008, “Konsep Dasar Web GIS”, diakses dari http://dennycharter.wordpress.com/2008/05/ 08/konsep-dasar-web-gis/, pada tanggal 13 Juni 2010 pukul 19.33 WIB.

[5] Data Statistik Indonesia, 2011, “Angka Partisipasi Kasar (APK)”, diakses dari http://www.datastatistikindonesia.com/content/view/711/711/, pada tanggal 4 Februari 2011 pukul 07.34 WIB.

[6] Jogiyanto H., 2003, "Sistem Teknologi Informasi”, Andi Offset, Yogyakarta.

[7] Nuryadin R., 2005, “Panduan Menggunakan MapServer”, Informatika, Bandung.

[8] Pemerintah Daerah Kota Serang, 2008, "Peraturan Daerah Kota Serang Nomor 9 Tahun 2008 tentang Pembentukan dan Susunan Organisasi Dinas Daerah Kota Serang”, di akses dari http://dprdkotaserang.com/index.php?option =com_phocadownload\&view $=$ category \&do wnload=22:no.9-tentang-pembentukan-dansusunan-organisasi-dinas-daerah-kotaserang\&id=3:peraturan-daerah-tahun- 
2008\&Itemid $=58$, pada tanggal 1 Maret 2011 pukul 13.45 WIB.

[9] Prahasta E., 2005, “Konsep-Konsep Dasar Sistem Informasi Geografis". Informatika, Bandung.

[10] Prahasta E., 2007, "Membangun Aplikasi Web-Based GIS dengan MapServer", Informatika, Bandung.

[11]Qolis N., 2010, "Pemetaan dan Analisa Sebaran Sekolah untuk Peningkatan
Layanan Pendidikan di Kabupaten Kediri dengan GIS”, diakses dari http://www.eepisits.edu/uploadta/downloadmk.php?id=912, pada tanggal 10 Mei 2010 pukul 14:30 WIB. [12] Sommerville I., 2003, "Software Engineering (Rekayasa Perangkat Lunak)”, Erlangga, Jakarta.

[13] Widodo A.P., dkk, 2004, "Buku Ajar Basis Data”, Jurusan Matematika Fakultas MIPA Universitas Diponegoro, Semarang. 